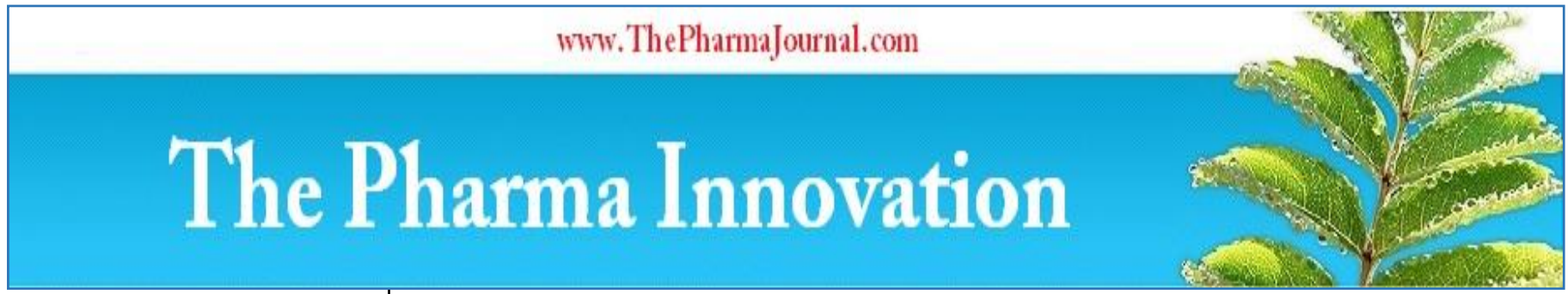

ISSN (E): 2277- 7695

ISSN (P): 2349-8242

NAAS Rating: 5.03

TPI 2020; 9(10): 395-398

(C) 2020 TPI

www.thepharmajournal.com

Received: 29-07-2020

Accepted: 09-09-2020

\section{Nagulwar MM}

Department of Food Business Management, College of Food Technology, Vasantrao Naik Marathwada Krishi Vidyapith, Parabhani, Maharashtra, India

\section{More DR}

Department of Food Business Management, College of Food Technology, Vasantrao Naik Marathwada Krishi Vidyapith, Parabhani, Maharashtra, India

\section{Mandhare LI}

Department of Food Business Management, College of Food Technology, Vasantrao Naik Marathwada Krishi Vidyapith, Parabhani, Maharashtra, India

\section{Nutritional properties and value addition of mushroom: A review}

\author{
Nagulwar MM, More DR and Mandhare LL
}

DOI: https://doi.org/10.22271/tpi.2020.v9.i10f.5266

\section{Abstract}

Mushrooms are the source of food and medicine throughout the world. They are considered as low calorie food that is highly nutritive with good quality of proteins and vitamins as these are excellent source of protein as well as vitamin B complex. Fat level in mushroom is low that includes healthy unsaturated fat. Mushrooms are the potential source of nutraceuticals as some have found to comprise important amount of bioactive components. They are known to possess promising antioxidative, cardiovascular, hypercholesterolemia, antimicrobial, hepatoprotective and anticancer effects. Mushrooms may be fried, baked, boiled, creamed, roasted, pickled, and stuffed. These consist of essential amino acids such as leucine, lysine which are lacking in many staple cereal foods. Their high amino acid content make them good supplement to cereal based Indian diets like papads, besan laddos, biscuits, cookies and breads.

Keywords: Mushrooms, nutraceuticals, bioactive substances

\section{Introduction}

At global level many species of eatable mushrooms have been used for diet and medication purposes. Mushroom is the best from nutrition point of view concerning human health,diet and it can also be used for hindrance of infection (Chang, 1996) ${ }^{[9]}$. Mushrooms are becoming more important in our diet, due to the nutritional value, related to high protein and low fat or energy contents (Agahar-Murugkar and Subbulakshmi, 2005) ${ }^{[2]}$. It is probable that from its earliest beginning man has utilized mushrooms as a food. (Rahi et al, 2004) ${ }^{[31]}$

Mushroom is an excellent source of folic acid, the blood building vitamin that prevents anaemia (Kannaiyan and Ramaswamy, 1980; Bisaria et al, 1987) ${ }^{[20,7] .}$

Studies have shown that mushrooms contain proteins especially amino acids that are essential to human health. Mushrooms are rich in leucine and lysine amino acids, which are commonly lacking in man staple cereal foods. Proteins are essential for general growth, body tissue repair, and even maintenance of healthy cells. Some mushroom proteins have antibacterial and anticancer properties. (Cheung, 2008; Wani, Bodha \& Wani, 2010; Xu et al., 2014) ${ }^{[42,40]}$

The word "mushroom" is most often applied to those fungi Basidiomycota and Agaricomycetes that have a stem (Stipe), a cap (Dileus) and gills (lamellae, sing. Lamella) on the underside of the cap. (Enas A.E., et al. 2006). The fat level in mushrooms is almost negligible. There is some fat in the cell walls, and this is sufficient fat to store vitamin D that mushrooms naturally generate after they have been exposed to sunlight. The fat that is present is mainly the healthy unsaturated fat. (Breene, 1990) ${ }^{[8]}$.

Mushroom is an excellent source of protein (44\%), crude fibre (7\%) and minerals (4\%). Calcium, Manganese, Magnesium and iron are important minerals which are found in mushrooms, also contains $27 \%$ moisture content \& $18 \%$ Carbohydrates content. The two most important bioactive components in mushrooms are Adenosine and Cordycepin. The total amino acid content in mushroom ranges from 35 to $37 \%$. Glutamic acid and Asparatic acid are two important amino acid found in mushroom (Hsu et al. 2002) ${ }^{[17]}$.

\section{Nutraceuticals}

In addition to the nutritional components found in edible mushrooms, some have been found to comprise important amounts of bioactive component. The content and type of biologically active substances may vary considerably in edible mushrooms, their concentrations of these substances are affected by difference in strain, substrate, cultivation, developmental stage, age, storage age, storage conditions, processing \& cooking practices. (P. Mattila, L. Barros, et al.)

$$
\sim 395 \sim
$$


The bioactive substances found in mushrooms can be divided into secondary metabolites (acids, terpenoids, polyphenols, sesquiterpenes, alkaloids, lactones, sterols, metal chelating agents, nucleotide analogs and vitamins), glycoprotein and polysaccharides, mainly B-glucans. New proteins with biological activities have also been found, which can be used in biotechnological processes and for development of new drugs including lignocellulose - degrading enzymes, lectins, protease and protease inhibitors, ribosomes -inactivating proteins, hydrophobins. (J. Erjavec, et al., 2012) ${ }^{[12]}$.

\section{Carbohydrates}

Polysaccharides are best known and most potent mushroom derived substances with anti-tumor and immunomodulating properties. Data on mushroom polysaccharides have been collected from hundreds of different species of $\beta$-glucans are well known for their biological activity, specifically related to immune system. Hence activating and reinforcing the host immune system seen to be the best strategy for inhibiting growth of cancer cells. Dried mushrooms are rich in carbohydrates. (https://nbd.nal.usda.gov)

Mushroom carbohydrates have been found in many cases to have anti cancer properties (Kalac, 2012) ${ }^{[19]}$. Carbohydrates, calculated by difference were also an abundant macronutrient that ranged from $52.90 \mathrm{~g} / 100 \mathrm{~g}$ in Lentinus edodus, $69.74 \mathrm{~g} / 100 \mathrm{~g}$ in Boletus sp., $78.24 \mathrm{~g} / 100 \mathrm{~g}$. Flammulina ventutipes and $57.88 \mathrm{~g} / 100 \mathrm{~g}$ in Agaricus bisporous. And the highest levels of carbohydrates were also found in Pleurotus eryngiii (king oyster) $(77.79 \mathrm{~g} / 100 \mathrm{~g})$ Although an extraordinarily high or appreciable level of total fiber was reported for A.bisporous, P.Seryngii and P.Ostreatus (Manzi et al., 2004) [26] Furthermore when comparing dried mushroom to fresh or frozen mushrooms, beta-glucan content of fresh mushrooms were higher than dried mushrooms.

\section{Proteins}

Total protein content in mushrooms varying between $21-50 \%$. The highest protein content was found for Agaricus bisporous $(58.05 \%)$ and lowest was found for $(23.55 \%)$. After drying, the protein content was increased significantly. (Tsungai Reid et al.,) Edible mushrooms are good source of protein, 200-250 $\mathrm{g} / \mathrm{kg}$ of dry matter, leucine,valine, glutamine, glutamic and asparatic acids are the most abundant. (E. Guiltamon et al.,) Protein is an important constituent of dry matter of mushrooms. (Aletor, 1995, Zrodlowski, 1995) [3, 43] Protein content of mushrooms depends on the composition of the substratum,size of pileus, harvest time and species of mushrooms.(Bano and Rajratnam 1982) ${ }^{[5]}$.

Mushrooms are very useful for vegetarian because they contain some essential amino acids which are found in animal proteins. (Verma et al., 1987) A need for food protein compels one to explore unconventional protein sources is the single cell protein. Mushrooms are the oldest single cell protein food for man. (Sawaya et al., 1985) The protein content of mushrooms are affected by number of mushrooms namely the type of mushrooms, the stage of development, the sampled level of nitrogen available and the location. (Flegg et al., 1977).

\section{Fats}

In mushrooms, the fat content is very low as compared to carbohydrates and proteins. The fats present in mushroom fruiting bodies are dominated by unsaturated fatty acids. (Singer, 1961) In general, mushrooms are low calorie foods since they provide low amount of fat (Diez and Alvarez, 2001). Mushrooms have $4.48 \%$ fats on dry weight basis. (Ogundana and Fagade, 1981) Total fat content in A.bisporous was reported to be 1.66 to $2.2 / 100 \mathrm{gm}$ on dry weight basis. (Kanwar et al., 1990) Polyunsaturated fatty acids are mostly contained in edible mushrooms; thus they may contribute to the reduction of serum cholesterol. It is noteworthy that transisomers of unsaturated fatty acids have not been detected in mushrooms. The major sterol produced by edible mushrooms is ergosterol, which shows antoxidant properties. (E. Guiltman, A. Garcia- Lafuente, M. Lozano, L.Barros, Baptista). It has been observed that a diet rich in sterols is important in prevention of cardiovascular diseases. (P. Kalac).

\section{Vitamins and minerals:}

Mushrooms are one of the best sources of vitamins especially vitamin B (Breene 1990, Mattila et al., 2002) ${ }^{[8]}$ Mushrooms contain appreciable amount of niacin, pantothenic acid and biotin. In addition, mushroom also contain folic acid and vitamin B12 which are absent in most of the vegetables. (ude and Ezenwugo, 2001)

Mushrooms are good sources of some B vitamins like Riboflavin (vitamin B2), Pantothenic acid (vitamin B5) and Niacin (vitamin B3). These B vitamin play an essential role in the nervous system and provide energy by breaking down carbohydrates, fats and protein. (Barbara et al.,2008) ${ }^{[6]}$

Mushrooms naturally produce vit. D when they see sunlight (or other source of UV light). Through the action of sunlight, they convet their abundant ergosterol to ergocalciferol (vit D2). Wild mushrooms in Europe commonly have 2-40 mcg vit D/100g. (Mattila 1994; Mattila 2002; Teichman 2007).

Store bought mushrooms are able to generate over $20 \mathrm{mcg}$ vitamin per $100 \mathrm{~g}$ that after being placed in sunlight for a couple of hours in the midday sun (Phillips,2013) The vitamin $\mathrm{D}$ in mushrooms is easy to absorb and effective in improving Vit.D status ( Urbain, 2011)

The fruiting bodies of mushrooms are charecterized by a high level of well assimilated mineral elements. Major mineral constituents in mushrooms are $\mathrm{K}, \mathrm{P}, \mathrm{Na}, \mathrm{Ca}, \mathrm{Mg}$ and elements like $\mathrm{Cu}, \mathrm{Zn}, \mathrm{Fe}, \mathrm{Mo}, \mathrm{Cd}$ form minor constituents. (Bano and Rajarathnum,1982, Bano et al., 1981; Chang 1982)

$\mathrm{K}, \mathrm{P}, \mathrm{Na}$ and $\mathrm{Mg}$ constitute about 56 to $70 \%$ of the total ash content of the mushrooms. (Li and Chang, 1982) While potassium alone forms $45 \%$ of the total ash. The content of potassium and sodium in A. bisporous was 300 and $28.2 \mathrm{ppm}$ resp. A. bisporous ash analysis showed high amount of $\mathrm{K}, \mathrm{P}$, $\mathrm{Cu}$ and Fe.(Abou and Helilah et al., 1987) A.bisporous contains $\mathrm{Ca}(0.04 \mathrm{~g}), \mathrm{Mg}(0.16 \mathrm{~g}), \mathrm{P}(0.75 \mathrm{~g}), \mathrm{Fe}(7.8 \mathrm{~g}), \mathrm{Cu}(9.4$ $\mathrm{mg}), \mathrm{Mn}(0.833 \mathrm{mg})$ and $\mathrm{Zn}(8.6 \mathrm{mg})$ per kilogram fresh weight.

\section{Utilization}

Mushrooms may be baked, fried, boiled, creamed, roasted, pickled and Stuffed. In India it is mostly consumed fresh. However, where mushrooms can be grown at ambient temperatures (i.e. hilly areas) but cannot be transported quickly to the consumption places, the only way to its utilization is its processing. They can be processed as canned, dried or frozen mushrooms. The vitamins in mushrooms are well retained during cooking, canning, dehydration. The moisture content in dried mushrooms should be between 5 and $8 \%$. Drying of mushrooms is done to remove free water to such a level that the biochemical and microbial activity are 
checked due to reduced water activity. (Sugana S. et al., 1995; Lidhoo C.K. and Agrawal Y. C., 2006) ${ }^{[25]}$

Dried mushrooms rich in calories $(300 \%)$, protein $(10 \%)$, carbohydrates $(80 \%)$ and total dietary fiber $(10 \%)$ (https://nbd.nalusda.gov)

Further their high lysine, leucine, valine, and tryptophan content make them good supplement to cereal based Indian diets.(Bano and Rajarathnam, 1988 and http://nbd.usda.gov.) These characteristics have made them a very valuable food. Mushroom powder have been used by many researchers for development of variety of food products like mathri and rava idli. (Singh V., and Verma A., 2013) ${ }^{[35]}$ Besan laddoo (Verma

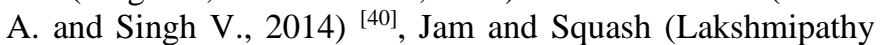
G. et al., 2013) and Biscuits (Wakchaure, G.C. et al., 2010) Regula J. and Michalowska, G. (2010) successfully prepared cookies and breads with 10 and $20 \%$ dried mushroom powder added to the flour and they recommended it as a good quality dietary supplement.

A large section of population consumes papads. Papad is one of the many preserved dehydrated form of foods. Since centuries, papad has been a popular snack item of India and many varieties are available commercially (Saxena et al., 1989)

Mushroom papads prepared can serve a very good source of protein, dietary fiber, calcium and phosphorous be increased with increased level of mushroom powder.

Mushroom soup powder is prepared by mixing powder of dried slices of white button mushroom or oyster mushroom with milk powder, corn flour and other ingredients. Delicious and crunchy mushroom biscuits were prepared by using the button / oyster mushroom powder and various ingredients viz., maida, sugar, ghee (bakery fats), mushroom powder, coconut powder, baking soda, ammonium bichromate and milk powder. Also it is used in the preparation of Mushroom nuggets, Mushroom ketchup, Mushroom candy and Mushroom preserve (Murabba) (G. C. Wakchaure, 2011)

\section{References}

1. Abou-Heilah AN, Kasionalsim MY, Khaliel AS. Chemical composition of the fruiting bodies of Agaricus bisporous. International Journal of Experimental Botony 1987;47(1):64-68.

2. Agahar-Murugkar D, Subbulakshmi G. Nutritional value of wild mushrooms collected from the khasi hills of Meghalaya. Food chemistry 2005;89(1):599-603.

3. Aletor VA. Compositional studies on edible tropical species of mushrooms. Food Chemistry 1995;54(1):265268.

4. Alofe FV, Odeyemi O, OKe OL. Three edible mushrooms from Nigeria: Their proximate and mineral composition. Plant foods for Human Nutrition 1995; 49(1):63-67.

5. Bano Z, Rajarathanam S. Pleurotus mushroom as a nutritious food In: Tropical mushrooms - Biological Nature and cultivation methods, (Chang S. T., Quimio T. H., eds.) The Chinese University Press, Hongkong 1982, 363-382.

6. Barbara R, Rosario L, Paula B, Andrade A, Rosa M, Rui $\mathrm{G}$, et al. Comparative study of phytochemical and antioxidant potential of wild edible mushroom caps and stipe. Food Chemistry. 2008;110(1):47-56.

7. Bisaria R, Madan M, Bisaria VS. Mineral content of the mushroom Pleurotus saior-caju cultivated on different agroresidues. Mushroom Journal Tropics. 1987:7(1):53-
60.

8. Breene WM. Nutritional and medicinal value of speciality mushrooms. Journal of Food Protection 1990;53(1):883-894.

9. Chang R. Functional properties of mushroom. Nutritional Reviews 1989;1996;4(1):91-93.

10. Dhar BL, Sharma SK. Medicinal mushroom product in India, present status and future trading Proc. $5^{\text {th }}$ International medicinal mushroom conference, Mycological Society of China, Nantong, China 2009, 403-406.

11. Enas AE, Sabahelkhier MK, Malaz MM. Nutritional composition and minerals content of five species of wild edible mushroom brought from UAE: Mushroom considered as protein source. International Journal of Advanced Research 2016;4(2):1108-1112.

12. Erjavec $\mathbf{J}$ et al. Protein of higher fungi from forest to application. Trends Biotechnology, 2012.

13. Guillamon E, Garcia-Lafuente A, Lozano M, Arrigo D, Rostango M, Villares MA et al. Edible mushrooms: Role in the prevention of cardiovascular diseases. Fitoterapia 2010;81(1):715-723.

14. Fasidi IO, Kadiri M. Changes in nutrient contents of two Nigerian mushrooms. Termitomyces robusts (Beeli) Heim and Lentinus subnudus (Berk), during sporophore development. Die Nahrung 1990a;34(1):141-420.

15. Florezak J, Lasota W. Cadmium uptake and binding by artificially cultivated (Pleuroyus ostreatus). Bromatol. Chem. Toksykol 1995;37(1):365-371.

16. Flegg PB, Maw G. Mushrooms and their possible contribution to world protein needs. Mushroom Journal 1977;48(1):395-403.

17. Hsu TH, Shiano LH, Hsieh C, Chang DM. A comparison of the chemical composition and bioactive ingredients of the Chinese medicinal mushroom, its counterfeit and mimic, and fermented mycelium of cordyceps sinensis. Food Chemistry 2002;78(1):463-469.

18. Kalac P. A review of chemical composition and nutritional value of wild growing and cultivated mushrooms. Journal of the Science of Food and Agriculture, 2013.

19. Kalac P. A review of Chemical composition and nutritional value of European species wild growing mushrooms: A review.

20. Kannaiyan S, Ramaswamy K. A hand book of mushrooms. Today and Tommorows publications, New Delhi, 1980, 39-43.

21. Kanwar N, Sharma BM, Sing BM. Nutritive value of Amanita caesarea (Scop. ex. Fr.) Quel. Indian Journal of Mycology and Plant Pathology 1990;20(1):249-250.

22. Barros L, Baptista P, Correia DM, Casal S, Oliveira B, Ferreira ICFR. Fatty acids and suger compositions and nutritional value of five wild edible mushrooms from Northest Portugal. Food Chemistry. 2007; 105(1):140145.

23. Barros L, Correia DM, Ferreira ICFR, Baptista P, SantosBuelga C. Optimization of the determination of tocopherols in Agaricus Sp. Edible mushrooms by a normal phase liquid chromatographic method. Food Chemistry 2008;110(4):1046-1050.

24. Li GSF, Chang ST. Nutritive value of Volvariella volvacea, In: Tropical mushrooms - Biological nature and cultivation methods (Chang ST, Quimio TH (eds) Chinese university press Hong Kong 1982, 199-219. 
25. Lidhoo CK, Agarwal YC. Hot- air oven drying characteristics of Button Mushroom safe drying Temperature. Mushroom research 2006;15(1):59-62.

26. Manzi et al. Commercial Mushrooms: Nutritional quality and effect of cooking. Food Chemistry 2004;84(2):201206.

27. Mattila PH, Pirronen VI, Uusi- R, Koivistoinen PE. Vit. $\mathrm{D}$ contents in edible mushroom. Journal of Agriculture and food chemistry 1994;42(1):2449-2453.

28. Orgundana SK, Fagade O. The nutritive value of some Nigerian edible mushrooms. In: Mushroom Science XI, Proceedings of the Eleventh International Scientific Congress on the Cutivation of Edible Fungi, Australia 1981, 123-131.

29. Mattila P, Konko K, Eurola M. Contents of vitamins, mineral elements, and some phenolic compounds in cultivated mushrooms, Journal of Agriculture and food chemistry 2001;49(5):2343-2348.

30. Phillips KM, Rasor AS. A nutritionally meaningful increase in the vitamin $\mathrm{D}$ in retail mushrooms is attainable by exposure to sunlight prior to consumption. Nutrition and Food Science 2013;3(6):2155-9600.

31. Rahi C, Shukla DK, Rajak KK, Pandey RCAK. Mushrooms and their substainable utiliation. Everyman's Science 2004;38(6):357-365.

32. Sawaya et al. Chemical composition and Nutritive value of Truffles of Saudi Arabia. Journal of Food Science. 50(2):450-453.

33. Saxena S, Rai RD. Post-Harvest technology of mushroom. Technical Bulletin. National centre for mushroom research and training 1990;12(1):30-40.

34. Singer R. Mushrooms and truffles. Bedfordshire, England: Leonard Hill Books, distributed in the United States by John Wiley and Sons (World Crop Books), New York, 1961.

35. Singh V, Verma. A. Nutritive value Evaluation of Mushroom fortified Indian recipes. International Journal of food, Nutrition and Dietetics. 2013;1(3):93-97.

36. Sugana Usha S, Narayanan M, Raghupathy VV, Gothandapani RL. Dehydration of Mushroom by Sun drying. Thin layer drying, Fluidized bed drying and solar cabinet drying. Journal of Food Science and Technology 1995;34(1):284-288.

37. Tsungai Reid et al. Effect of cooking and preservation of on nutritional and phytochemical composition of the mushroom the mushroom Amanita Zambiana. Food Science and Nutrition 2016;5(3).

38. Ude CM, Ezenwugo SE, Agu RC. Composition and Food Value of Sclerotium and Edible Mushroom (Pleurotus Tuber- Regium). Journal Food Science Technology 2001;38(6):612-614.

39. Urbain P, Singler F, Ihorst G, Biesalski HK, Bertz H. Bioavailability of vitamin $\mathrm{D}_{2}$ from UV-B- Irradiated button mushrooms in healthy adults deficient in serum 25 hydroxyvitamin D: a randomised controlled trial. European Journal of Clinical Nutrition 2011;65(8):965971.

40. Verma A, Singh V. Nutritional value and organoleptic evaluation of mushroom powder fortified Indian recipe: Besan laddu. Asian Journal of Home Science 2014;9(1):78-81.

41. Wakchaure GC, Shirur M, Manikandan K, Rana L. Development and evaluation of Oyster Mushroom value added products. Mushroom Research 2010;19(1):40-44.
42. Wani RH, Bodha, Wani AH. Nutritional and medicinal importance of mushrooms. Journal of medicinal plants research 2001;4(24):2598-2604.

43. Zrodlowski Z. The influence of washing and peeling of mushrooms Agaricus bisporous on the level of heavy metal contaminations. Polish Journal of Food and Nutrition Sciences 1995;4(1):23-33. 